12. Lock JE, Olley PM, Coceani F, Swyer PR, Rowe RD 1979 Use of prostacyclin in persistent fetal circulation. Lancet 1:1343

13. Lowry OH, Rosebrough NJ, Farr AL, Randall RJ 1951 Protein measurement with the Folin phenol reagent. I Biol Chem 193:265

14. Miller HC, Futvakul $P 1968$ Birthweight, gestational age and sex as determining factors in the incidence of respiratory distress syndrome of prematurely born infants. Pediatrics 72:628

15. Nielsen HC, Zinman HM, Torday JS 1982 Dihydrotestosterone inhibits fetal rabbit pulmonary surfactant production. J Clin Invest 69:611

16. Nielsen HC. Torday JS 1981 Sex differences in fetal rabbit pulmonary surfactant production. Pediatr Res 15:1245

17. Ohuchi K, Watanabe M. Numajiri N. Tsurufuji S 1982 Phospholipase $A_{2}$ activity in carrageenin-induced inflammatory tissue of rats. Biochem Pharmacol 31:2993

18. Powell WS 1980 Rapid extraction of oxygenated metabolites of arachidonic acid from biological samples using octadecylsilyl silica. Prostaglandins 20:947

19. Powell WD, Solomon S 1980 Effects of prostaglandins on the adenylate cyclase activity of lungs from fetal rabbits. Endocrinology 107:1469

20. Powell WS, Solomon S 1978 Biosynthesis of prostaglandins and thromboxane $\mathrm{B}_{2}$ by fetal lung homogenates. Prostaglandins 15:35
21. Taeusch HW, Frigoletto F, Kitzmiller J, Avery ME, Hehre A, Fromm B Lawson E, Neff RK 1979 Risk of respiratory distress syndrome after prenatal dexamethasone treatment. Pediatrics 63:64

22. Taylor L, Polgar P, McAteer JA, Douglas WHJ 1979 Prostaglandin production in type II alveolar epithelial cells. Biochim Biophys Acta 572:502

23. Terragno A, Rydzik R, Terragno NA 1981 High performance liquid chromatography and UV detection for the separation and quantitation of prostaglandins. Prostaglandins 21:101

24. Tsai MY, Josephson MW, Brown DM 1981 Fetal rat lung phosphatidylcholine synthesis in diabetic and normal pregnancies: a comparison of prenatal dexamethasone treatments. Biochim Biophys Acta 664:174

25. Tsai MY, Josephson MW, Donhowe J 1983 Delayed pulmonary phosphatidylglycerol synthesis and reversal by prenatal dexamethasone in fetal rats of streptozotocin-diabetic mothers. Exp Lung Res 4:315

26. Tsai MY, Josephson MW, Handschin B, Brown DM 1983 The effect of prenatal dexamethasone on fetal rat lung prostaglandin synthesis. Prostaglandin Leukotriene Med 11:171

27. Tsai MY, Schallinger LE, Josephson MW, Brown DM 1982 Disturbance of pulmonary prostaglandin metabolism in fetuses of alloxan diabetic rabbits. Biochim Biophys Acta 712:395

\title{
A Longitudinal Study of Rhesus Monkey (Macaca mulatta) Milk Composition: Trace Elements, Minerals, Protein, Carbohydrate, and Fat
}

\author{
BO LÖNNERDAL, CARL L. KEEN, CAROL E. GLAZIER, AND JOHN ANDERSON \\ Department of Nutrition and California Primate Research Center [J.A.], University of California, Davis,
} California 95616

\begin{abstract}
Summary
The concentrations of iron, copper, zinc, calcium, magnesium, sodium, potassium, protein, carbohydrate, and fat were analyzed in milk from rhesus monkeys (Macaca mulatta) during the course of lactation. Concentrations of iron, copper, zinc, magnesium, sodium, potassium, and protein were higher in milk of early lactation (colostrum) than in mature milk, while concentrations of calcium increased with lactation time. Concentrations of zinc in monkey colostrum and mature milk were similar to that of human milk, while iron, copper, calcium, and protein concentrations were higher than in human milk.
\end{abstract}

There is a paucity of data in the literature regarding the effects of maternal diet on the composition of breast milk, and the resulting impact on the breast-fed infant. In addition, there is fragmentary information on the extent of nutrient utilization from milk by the breast-fed infant. While epidemiological studies can contribute to an understanding of these areas, data obtained from such studies are often difficult to interpret due to the lack of rigid definition of the maternal and infant environment, and the lack of appropriate controls. For ethical reasons, there are

Received July 12, 1983; accepted February 7, 1984.

Requests for reprints should be addressed to Dr. B. Lönnerdal, Department of Nutrition, University of California, Davis, CA 95616.

This research was supported in part by National Institutes of Health Grant RR 00169. several limitations in designing studies in which the investigator manipulates the maternal environment since the diet must always be kept within "normal" and "appropriate" limits; the number of blood samples taken from the infants should be few, and only rarely can justification be made for soft tissue sampling. Furthermore, if the experimental manipulation appears to be causing an insult to the infant, the study should be halted, or changed, in the interest of the child. For these reasons, it is necessary to identify and develop animal models which can be used for the study of maternal-infant nutrition. While several laboratory animals (primarily rodents) have been used to evaluate the effects of maternal dietary environment on milk composition, and the subsequent suckling outcome, the gross composition of milk from most of these species is not well matched to that of the human $(12,13,17)$.

In order to evaluate the possibility of using a non-human primate as an animal model for milk composition, and metabolism studies, with special emphasis on trace elements, we have analyzed the nutrient composition of rhesus monkey milk, and noted changes throughout the course of lactation. These data are compared with data on human milk composition.

\section{MATERIALS AND METHODS}

Animals. Milk samples were obtained from healthy rhesus monkeys (Macaca mulata) at the California Primate Research Center. The animals were housed in five $4500-\mathrm{m}^{2}$ outdoor cor- 
rals. Each corral contained approximately 25-35 adult females, their offspring from recent years and several adult males. Diet consisted of commercial monkey chow (Purina Monkey Chow, Ralston Purina Co., St. Louis, MO) plus water ad libitum. In addition, the monkeys were observed to feed extensively on the grass ground cover which consisted primarily of fescue and/or Bermuda grass.

Milking procedure. Lactating monkeys $(n=104)$ were immobilized with ketamine hydrochloride (Vetalar, Parke-Davis, Detroit. MI). Ocytocin (2 IU) was given intramuscularly to stimulate milk flow and the monkeys were milked by gentle hand stripping of the teats. The free-flowing milk was collected in acid-washed 5 -ml plastic vials. In order not to cause undue stress, teats were not completely emptied; however, the volumes collected (5-10 $\mathrm{ml}$ ) should represent a pool of the major part of the milk available. Collected milk was stored frozen $\left(-20^{\circ} \mathrm{C}\right)$ until analysis. All monkeys were milked only once. The day of parturition was designated day 0 of lactation. Analyses were performed on single milk samples.

Analytical inethods. Protein was determined in milk samples by a modified Lowry method (23) which minimizes interference from fat. Lactose was analyzed enzymatically using lactase and glucose oxidase according to Dahlquist (7) following precipitation of protein according to Somogyi (27). Fat was determined by a colorimetric method using the sulfuric acid-vanillin reaction (30) soon after collection to minimize lipolysis. Phosphate was analyzed according to Eibl and Lands (10). All these methods have been well established for human milk analysis and critically evaluated against other analytical methods (18). Energy content

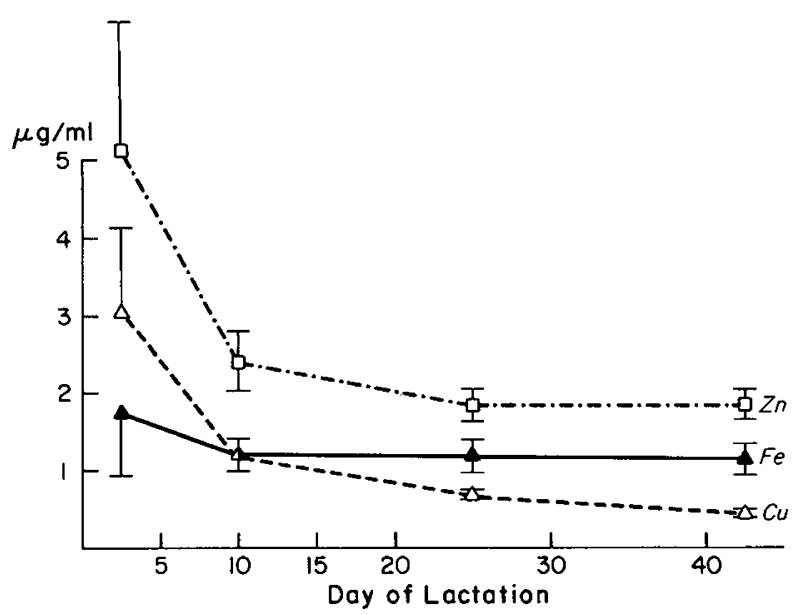

Fig. 1. Milk iron, copper, and zinc concentrations in the monkey. Values shown are mean \pm SEM. was estimated by conventional energy factors for carbohydrate, fat, and protein.

Atomic absorption spectrophotometry. Milk samples $(1 \mathrm{ml})$ were wet ashed with $16 \mathrm{~N}$ nitric acid $(2 \mathrm{ml}$ of Ultrex grade, J. T. Baker Chemical Co., San Francisco, CA), concentrated by evaporation, and diluted with distilled deionized water (5). Calcium, magnesium, iron, copper, and zinc were determined by flame atomic absorption spectrophotometry, and sodium and potassium by emission spectrophotometry (IL 551, Instrumentation Laboratories, Wilmington, MA). For calcium and magnesium analysis, the diluted ashed samples were diluted further with $0.1 \%$ lanthanum chloride in order to reduce matrix interference (4). The wet ashing method used has been documented to be superior to dry ashing methods (6). Typical recoveries of added metals range between 98 and $102 \%$.

Statistical methods. To identify when changes in milk composition occurred, data were grouped in four time periods and analyzed by Student's $t$ test. Comparisons were made between one time period and that time period immediately following.

\section{RESULTS AND DISCUSSION}

Iron concentration of monkey milk was high in early lactation, and then decreased to a value of approximately $1.2 \mu \mathrm{g} / \mathrm{ml}$ (Fig. 1). The absolute concentration of iron in monkey milk is considerably higher at all times than that of human milk (Table 1), though the change in milk iron concentration found during lactation for the monkey is similar to that reported for human milk (25). Despite the difference in absolute milk iron concentrations. the monkey may be an excellent model for studying milk iron metabolism in humans, since the molecular localization of iron in monkey milk appears similar to that of human milk. In particular, much of the iron in monkey milk $(\sim 50 \%)$ is bound to lactoferrin (8), an iron-binding protein present in human milk, which is absent, or found only in trace amounts, in the milk of most other species $(20,21)$. It has been hypothesized that it is in part the presence of lactoferrin in human milk which accounts for the high bioavailability of iron from human milk, compared to iron bioavailability from other milks such as cow's milk (11). In addition, it has been suggested that lactoferrin may have an important role as an antibacterial agent for the suckling infant (2). The observation that lactoferrin is present in monkey milk in a high concentration $(>2 \mathrm{mg} / \mathrm{ml})$ suggests that this species may be used to test the above hypotheses.

Similarly, the copper concentration was higher in monkey colostrum than in mature monkey milk. The pattern of decreasing milk copper levels was different than the iron levels which dropped during early lactation, and then remained steady; copper levels dropped throughout the lactation period with values late in lactation only $20 \%$ of initial values (Fig. 1). The pattern for

Table 1. Composition of monkey milk during lactation*

\begin{tabular}{|c|c|c|c|c|c|}
\hline \multirow[b]{2}{*}{ Nutrient } & \multicolumn{5}{|c|}{ Days of Lactation } \\
\hline & $0-5$ & $6-15$ & $16-35$ & $36 \rightarrow$ & Human Mature Milk $\dagger$ \\
\hline Iron, $\mu \mathrm{g} / \mathrm{ml}$ & $1.76 \pm 0.84(9)$ & $1.21 \pm 0.20(15)$ & $1.18 \pm 0.22(43)$ & $1.15 \pm 0.19$ & $0.25 \pm 0.03(18)$ \\
\hline Copper, $\mu \mathrm{g} / \mathrm{ml}$ & $3.04 \pm 1.09(9)$ & $1.21 \pm 0.18(15) \ddagger$ & $0.60 \pm 0.04(43) \ddagger$ & $0.46 \pm 0.04(37) \ddagger$ & $0.27 \pm 0.02(18)$ \\
\hline Zinc, $\mu \mathrm{g} / \mathrm{ml}$ & $5.15 \pm 1.64(9)$ & $2.41 \pm 0.38(15) \ddagger$ & $1.84 \pm 0.20(43) \ddagger$ & $1.86 \pm 0.18(37)$ & $1.35 \pm 0.13(18)$ \\
\hline Calcium, $\mu \mathrm{g} / \mathrm{ml}$ & $350 \pm 26(9)$ & $364 \pm 27(15)$ & $420 \pm 10(43) \ddagger$ & $392 \pm 14(37) \ddagger$ & $270 \pm 14(18)$ \\
\hline Magnesium, $\mu \mathrm{g} / \mathrm{ml}$ & $49.6 \pm 12.1(9)$ & $31.5 \pm 3.6(15) \ddagger$ & $32.9 \pm 3(43)$ & $30.7 \pm 2.3(37)$ & $33.6 \pm 1.1(18)$ \\
\hline Sodium, $\mu \mathrm{g} / \mathrm{ml}$ & $171 \pm 64(9)$ & $95.9 \pm 17.7(15)$ & $89.4 \pm 8.6(43)$ & $81.8 \pm 6.5(37)$ & $184 \pm 33(18)$ \\
\hline Potassium, $\mu \mathrm{g} / \mathrm{ml}$ & $367 \pm 33(9)$ & $242 \pm 17(15) \ddagger$ & $260 \pm 8(43)$ & $276 \pm 10(37)$ & $470 \pm 19(18)$ \\
\hline Protein, \% & $2.49 \pm 0.26(5)$ & $2.28 \pm 0.09(7)$ & $2.34 \pm 0.07(13)$ & $2.35 \pm 0.09(19)$ & $1.32 \pm 0.04(18)$ \\
\hline Fat, $\%$ & $5.29 \pm 0.97(4)$ & $5.42 \pm 0.51(9)$ & $4.57 \pm 0.52(17)$ & $4.92 \pm 0.50(21)$ & $4.58 \pm 1.39(18)$ \\
\hline Lactose. $\%$ & $7.79 \pm 0.13(6)$ & $8.06 \pm 0.03(8)$ & $7.91 \pm 0.06(18)$ & $7.92 \pm 0.04(25)$ & $7.13 \pm 0.18(18)$ \\
\hline $\mathrm{kcal} / 100 \mathrm{ml}$ & 88.7 & 90.1 & 82.2 & 85.4 & 75.0 \\
\hline
\end{tabular}

${ }^{*}$ Data are expressed as mean \pm SEM. No. of samples are shown in parentheses.

$\uparrow$ Human milk values are based on data obtained in the author's laboratory. Mature milk was collected at 3 months postpartum.

$\ddagger$ Significantly different from preceding time period $(p<0.05)$. 
monkey milk copper levels during lactation is different than that of human milk, where the majority of the decrease occurs during early lactation (29). As seen with milk iron concentration, the absolute concentration of copper in monkey milk is higher than that of human milk. We have not yet compared the relative molecular localization of copper in monkey milk with copper localization in human milk.

The lactation pattern of zinc concentration in monkey milk is similar to that reported for human milk (29), with high values found in colostrum, which then decreased rapidly (Fig. 1). The absolute concentration of zinc is similar between human and monkey milk (Table 1). We have previously shown that in monkey milk a significant amount of the zinc is bound to the low molecular weight ligand, citrate (16), as is true for human milk (19). The non-citrate bound zinc is also distributed similarly in the milk of the two species, but very different from most other species studied (16). As seen with iron absorption from human milk, it has been suggested that the high bioavailability of zinc from human milk relative to cow's milk may be due to a difference in molecular localization of zinc in the milks $(9,24)$. The monkey thus presents a model in which this hypothesis may be tested.

Similar to the lactation pattern seen in human milk, the calcium concentration of monkey milk increased slightly during lactation (Fig. 2); however, the levels of calcium are slightly higher in monkey milk (Table 1). In a limited number of samples, phosphate was analyzed and it was found that the calcium:phosphorus ratio of monkey milk is similar to that of human milk, being $\sim 2: 1$.

As in human milk, magnesium concentrations were higher in monkey colostrum than in mature monkey milk (Fig.2). The absolute concentration of magnesium in human and monkey milk is similar (Table 1).

Sodium and potassium concentrations were slightly higher in monkey colostrum than in mature monkey milk (Fig. 3). The concentrations of sodium and potassium are lower in monkey milk than in human milk (Table 1). The monkey milk as a result has a similar osmolarity to that of human milk since monkey milk is higher in calcium and protein than human milk. Thus, the renal solute load from monkey milk should be very similar to that of human milk.

In contrast to human milk which has a pronounced lactation pattern with high levels of protein during early lactation, and low levels in mature milk (15), monkey milk protein concentrations decreased only slightly with lactation time (Fig. 4). As mentioned above, the protein concentration of monkey milk is higher than that of human milk (Table 1), although the casein:whey ratio of monkey milk is similar to that of human milk $(1: 4)(14)$

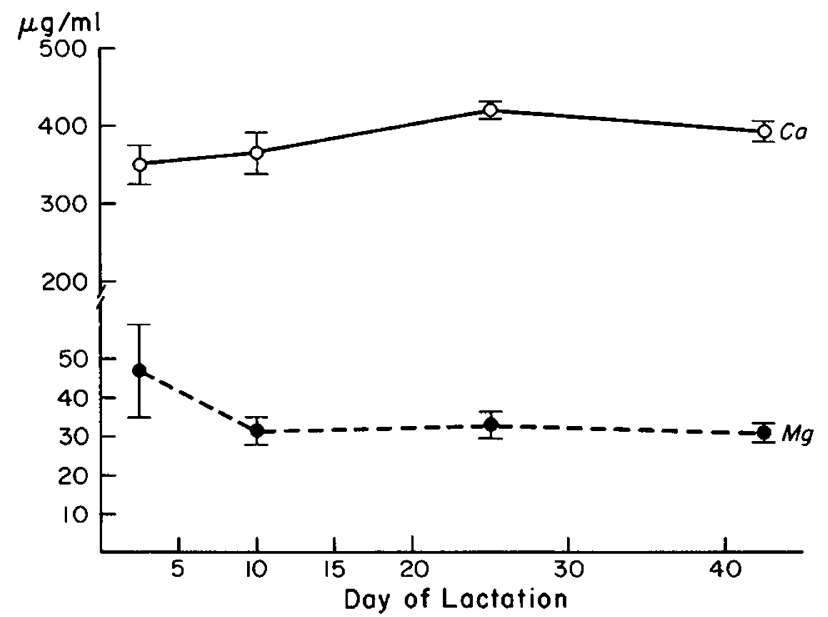

Fig. 2. Milk calcium and magnesium concentrations in the monkey. Values shown are mean \pm SEM.

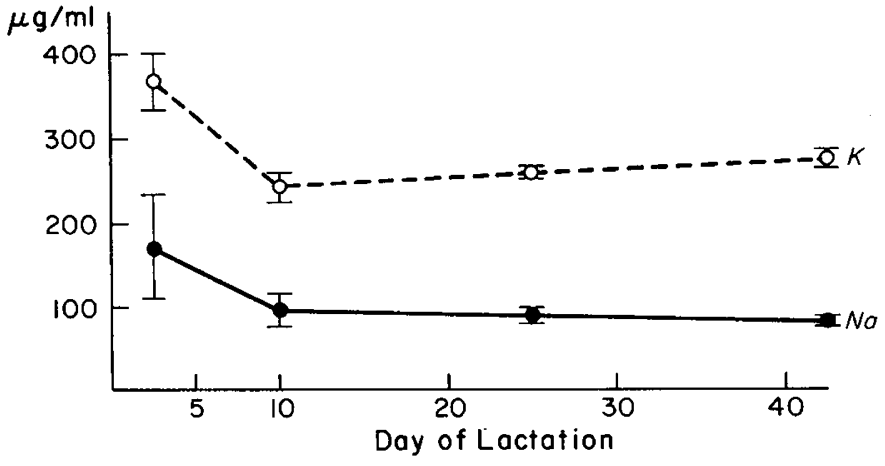

Fig. 3. Milk sodium and potassium concentrations in the monkey. Values shown are mean \pm SEM.

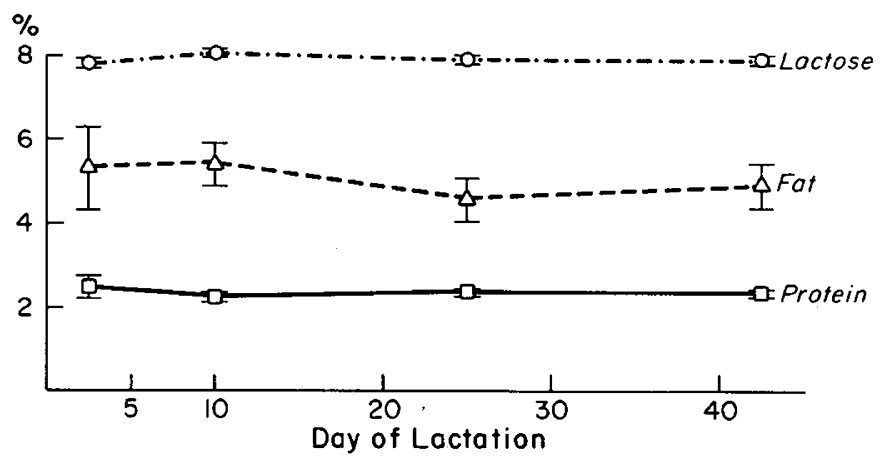

Fig. 4. Milk fat, lactose, and protein concentrations in the monkey. Values shown are mean \pm SEM.

Similar to those in human milk, fat and lactose contents did not vary much with the stage of lactation (Fig. 4) and the absolute concentrations of fat and lactose are similar between the two species. As a result, caloric contents of human milk and monkey milk are similar (Table 1). While there have been studies on monkey milk composition, the milk of rhesus monkeys has not been studied in detail on a longitudinal basis and for all primates trace element information is scarce. Van Wagenen et al. (28) studied milk from rhesus monkeys and found that the concentration of protein was $2.1 \%$, fat was $3.9 \%$, and carbohydrates was $5.9 \%$. Bahgat et al. (1) also analyzed protein, fat, and lactose in rhesus monkey milk. Although our values are slightly higher in general, they are in good agreement with their data. Milk of other laboratory primates, such as the baboon (3), appear to have similar gross comparison to that of the rhesus monkey. The ash content of primate milk appears higher than in human milk (3), probably reflecting the higher concentrations of calcium found in our study. The composition of both whey proteins and casein in monkey milk has a remarkable degree of similarity to those of human milk (26), and are different from virtually all other species analyzed. In addition, the ratio of casein and whey proteins in monkey (cynomolgus) milk appears similar to human milk, resulting in a similar amino acid composition (22). Fatty acid composition of monkey milk also appears similar to human milk.

Overall, nutrient composition, caloric density, and osmolarity of monkey milk and human milk are similar. Although the concentrations of protein, iron, and copper are higher in monkey milk than in human milk, the composition and/or distribution among components appears to be similar between the two species. Thus, this non-human primate should be an excellent model for studies on milk nutrient metabolism in early life when results are to be extrapolated to humans.

\section{REFERENCES}

1. Bahgat MR, Atkinson LE, Brinson AO, Segal SJ 1975 Treatment of postpartum rhesus monkeys with progestogen: appearance in milk and effects of lactation. 
Contraception 12:665

2. Bullen JJ. Rogers HJ, Leigh L 1972 Iron-binding proteins in milk and resistance to Escherichia coli infection in infants. Br Med J 1:69

3. Buss DH 1968 Gross composition and variation of the components of baboon milk during natural lactation. J Nutr 96:421

4. Chrisitan GD. Feldman FJ 1970 Atomic Absorption Spectroscopy: Applications in Agriculture and Biology and Medicine. Wiley Interscience, New York

5. Clegg MS. Keen CL. Lönnerdal B. Hurley LS 1981 Influence of ashing techniques on the analysis of trace elements in animal tissue. I. Wet ashing. Biol Trace Elem Res 3:107

6. Clegg MS, Keen CL. Lönnerdal B. Hurley LS 1981 Influence of ashing techniques on the analysis of trace elements in biological samples. II. Dry ashing. Biol Trace Element Res 3:237

7. Dahlquist A 1964 Method for assay of intestinal disaccharidases. Anal Biochem $7: 18$

8. Davidson L. Lönnerdal B (1984) Isolation and characterization of monkey milk lactoferrin and its brush border receptor. Fed Proc 43:468

9. Eckhert C. Sloan M. Duncan JR. Hurley LS 1977 Zinc binding: a difference between human and bovine milk. Science 195:789

10. Eibl H. Lands WEM 1969 A new sensitive determination of phosphate. Anal Biochem 30:51

11. Fransson GB. Lönnerdal B 1982 The role of lactoferrin in human milk. In: Saltman P. Hegenauer J, (eds) The Biochemistry and Physiology of Iron. Elsevier/North-Holland, New York. p 305

12. Hambraeus L 1977 Proprietary milk versus human breast milk in infant feeding. Pediatr Clin N Am 24:17

13. Henness R. Sloan RE 1970 The composition of milks of various species. A review. Dairy Sci Abstr 32:599

14. Lönnerdal B. Forsum E 1980 Casein content of human milk. In: Hambraeus L (ed) Nutrition in Europe/Proceedings of the Third European Nutrition Conference. Almquist and Wiksell International, Stockholm, p 139

15. Lönnerdal B. Forsum E. Hambraeus L 1976 A longitudinal study of the protein, nitrogen and lactose contents of human milk from Swedish wellnourished mothers. Am J Clin Nutr 29:1127
16. Lönnerdal B. Keen CL. Golub M, Hurley LS, Gershwin ME 1983 Effect of marginal zinc deficiency on primate milk composition. Am J Clin Nutr $37: 728$

17. Lönnerdal B. Keen CL. Hurley LS 1981 Iron, copper, zinc and maganese in milk. Annu Rev Nutr 1:149

18. Lönnerdal B. Smith C. Keen CL (1984) Analysis of breast milk-current methodologies and future needs. Pediat Gastroenterol Nutr 3:290

19. Lönnerdal B. Stanislowski AG. Hurly LS 1980 Isolation of a low molecular weight zinc binding ligand from human milk. J Inorg Biochem 12:71

20. Masson P $1970 \mathrm{La}$ Lactoferrine, pp 171-184. Editions Arscia, Bruxelles, Belgium

21. Masson PL. Heremans JF 1971 Lactoferrin in milk from different species. Comp Biochem Physiol B 39:119

22. Nishikawa I, Kawanishi G, Cho F, Honjo S, Hatakeyama T, Wako H 1976 Chemical composition of cynomolgus monkey milk. Exp Anim 25:253

23. Peterson GL 1977 A simplification of the protein assay method of Lowry et al. which is more generally applicable. Anal Biochem 83:346

24. Sandström B. Cederblad A. Lönnerdal B 1983 Zinc absorption from human milk cow's milk and infant formulas. Am J Dis Child 137:726

25. Siimes MA, Vuori E, Kuitunen P 1979 Breast milk iron-a declining concentration during the course of lactation. Acta Paediatr Scand 68:29

26. Sloan RE, Jenness R, Kengon AL, Regehr EA 1961 Comparative biochemical studies of milks. I. Electrophoretic analysis of milk proteins. Comp Biochem Physiol 4:47

27. Somogyi M 1945 A new reagent for the determination of sugars. J Biol Chem 160:61

28. Van Wagenen G. Himwich HE Catchpole HR 1941 Composition of the milk of the monkey ( $M$. mulatla). Proc Soc Exp Biol Med 48:133

29. Vuori E, Kuitunen P 1979 The concentrations of copper and zinc in human milk. Acta Paediatr Scand 68:33

30. Zollner N, Kirsch K 1962 Uber die quantitative bestimmung von lipoiden (mikromethode) mittels der vielen naturlichem lipoiden (allen bekannten plasmolipoiden) gemeinsamen sulfophosphovanillin-reaktion. Gesamte Exp Med 135:545

\title{
Decreased Calcium Content and ${ }^{45} \mathrm{Ca}^{2+}$ Uptake in Down's Syndrome Blood Platelets
}

\author{
E. E. MCCOY AND J. M. SNEDDON \\ Department of Pediatrics, University of Alberta, Edmonton, Alberta, Canada T6G $2 G 3$
}

\begin{abstract}
Summary
Total intracellular $\mathrm{Ca}^{2+}$ and ${ }^{45} \mathrm{Ca}^{2+}$ uptake has been studied in blood platelets from subjects with Down's syndrome and matched controls. In Down's subjects, $\mathrm{Ca}^{2+}$ levels $\left(85.5 \pm 5.9 \mathrm{nmol} / \mathbf{1 0}^{-9}\right.$ platelets) were significantly lower than controls, $174 \pm 10.0$ $\mathrm{nmol} / 10^{-9}(p<0.0005)$. A similar reduction was seen in calcium uptake (Down's platelets, $0.79 \pm 0.06 \mathrm{nmol} / 10^{-9}$ platelets; controls, $1.17 \pm 0.07 \mathrm{nmol} / 10^{-9}$ platelets, $p<0.005$ ). The low levels of intracellular $\mathrm{Ca}^{2+}$ may be related to decreased granular storage of serotonin, and the decreased $\mathrm{Ca}^{2+}$ uptake with impaired transport by intracellular $\mathrm{Ca}^{2+}$-accumulating organelles such as the dense tubular system.
\end{abstract}

\section{Abbreviation}

\section{PRP, platelet-rich plasma}

Calcium ions play an essential role in initiating or terminating cellular functions by mechanisms that either involve the influx

Received July 25. 1983; accepted March 12, 1984.

This work was supported by a grant from the Canadian Medical Research Council. of $\mathrm{Ca}^{2+}$ or the intracellular translocation of $\mathrm{Ca}^{2+}(11)$. In blood platelets, $\mathrm{Ca}^{2+}$ content can be described as a three-compartment space, a surface component, and two intracellular components, one rapidly exchangeable with external $\mathrm{Ca}^{2+}$ and the other virtually nonexchangeable. The nonexchangeable space represents $\mathrm{Ca}^{2+}$ sequestered in subcellular storage granules, and alteration of $\mathrm{Ca}^{2+}$ binding and/or fluxes in the other compartments has an important role in the process of platelet aggregation and exocytosis (1). In subjects with Down's syndrome, blood platelets have decreased $\mathrm{Na}^{+} / \mathrm{K}^{+}$-ATPase activity and increased intracellular $\mathrm{Na}^{+}(9)$. In erythrocytes, it has been reported that $\mathrm{Na}^{+} / \mathrm{K}^{+}-$ ATPase is inhibited by increases in intracellular $\mathrm{Ca}^{2+}(2,3)$, which may lead to raised intracellular $\mathrm{Na}^{+}(13)$; thus, it seemed pertinent to determine the $\mathrm{Ca}^{2+}$ content of blood platelets from subjects with Down's syndrome as a possible factor contributing to decreased $\mathrm{Na}^{+} / \mathrm{K}^{+}$-ATPase activity.

\section{MATERIALS AND METHODS}

Materials. ${ }^{45} \mathrm{CaCl}_{2}(0.6 \mathrm{mCi} / \mathrm{mg})$ was obtained from $\mathrm{New}$ England Nuclear. $\mathrm{LaCl}_{2}$ was spectrographic grade from Fisher 